\title{
Experiential Learning Model and Awareness Training Model to Increase Student Multicultural Competence
}

\author{
Permata Sari ${ }^{1}$, Ferisa Prasetyaning Utami², Ike Kurnia Ani Khusana ${ }^{3}$ \\ ${ }^{1}$ UIN Raden Intan Lampung \\ ${ }^{2}$ Universitas Slamet Riyadi \\ ${ }^{3}$ IAIN Samarinda \\ permataonte193@gmail.com
}

Submitted: 2019-11-10, Revised: 2019-11-15, Accepted: 2019-12-03

\begin{abstract}
The emergence of conflicts between cultures is due to the lack of multicultural competence by individuals to respect the existence of other people who are of different cultures. This study aims to determine the effectiveness of experiential learning models and awareness training to remind multicultural competencies of BKPI students. This research is a quantitative research with true experiment type which uses Nonequivalent Control Group Design. The subjects in this study were 16 students who had multicultural competencies in the low category. The instrument used in this study is a multicultural competency scale. The results of the study were analyzed with the Wilcoxon signed-rank test to measure student scores before and after treatment was given. The Mann-Whitney $U$ test is used to measure the comparison of models that are more effectively used. The results show experiential learning is more effective than awareness training.
\end{abstract}

Keywords: Awareness Training; Experiential Learning; Multicultural Competence

\section{Introduction}

Cultural diversity is a legacy with the characteristics of Indonesia. Indonesia is a country with a variety of cultures, races, ethnicities, and religions, so it is called a multicultural society. Indonesia is a country with a diversity of cultures, races, ethnicities, and beliefs. The cause of diversity is due to the geographical conditions of Indonesia, which has many islands. This diversity can be an obstacle that causes conflict in people's lives. Someone who does not understand cultural differences can cause problems ranging from suspicion, stereotypes, and other battles. Indonesian society, which is multicultural, has the potential to cause group segmentation, with weak consensus, social conflicts, and social jealousy, and forced integration can weaken the space for individual life (Ridwan, 2015).

Some inter-cultural conflicts that arise, for example, there are cases of students from Papua that occurred in Surabaya (Merdeka.com 30/09/2019). The case of Papuan student racism in Surabaya has even developed in cyberspace wherein social media, and people can freely say hatred with others (Merdeka.com 13/09/2019). Conflicts are interpreted as a lack of multicultural competencies possessed by individuals to respect the existence of other people of different cultures.

Forms of intolerance and racism also develop in the school and educational environment in the form of bullying, insulting friends based on religion, discriminating between friends based on religion, and mistreating friends (Charlina, Utama, \& Farabi, 2017). The intolerant behavior of these students indicates that the lack of multicultural awareness in social interaction has the potential to cause divisions and hostility.

The emergence of conflicts caused by intolerance among students and students need to get individual attention to planting multicultural awareness attitudes (Bulantika, 2017). As something that is considered necessary, a sense of intolerance needs to get individual attention, especially from the scientific point of view of Guidance and Counseling, which has the task of developing students' abilities in behaving according to norms and values. In line with the results of research that explains the increase intolerance, there are no more problems 
related to culture, so it does not lead to social conflict (Yusra, 2018). Besides introducing and applying creative and innovative cultural models can be a way to increase tolerance in individuals (Tangidy \& Setiawan, 2016). One crucial role that Counselors and Prospective Counselors need to have to develop an attitude of multicultural awareness is to have multicultural competence. The assumption is that if a counselor can have multicultural awareness both within the scope of practice and daily behavior, it will be a role model for students to develop an attitude of tolerance and respect for all forms of cultural differences.

The counselor is someone who is a professional in the field of guidance and counseling in charge of planning and responsible for carrying out services in the education unit in the school. In carrying out their duties, they must have specific competencies, one of which is a multicultural competency that is useful for understanding the cultural diversity of the counselor (Riswanto, Mappiare-AT, \& Irtadji, 2017). A counselor must be aware of how their own cultural identity can influence interpersonal dynamics in counseling practice. Also, counselors' understanding of collective experiences based on race and ethnicity can contribute to higher sensitivity to intercultural group dynamics.

Counseling as a process of cultural encounters has three main elements in practice. First, counselors and counselees who have different cultural backgrounds and counseling practices are carried out in the cultural setting/counselor's place, second, counselors and counselees of different cultures and counseling practices are carried out in the counselee setting, third, counselors and counselees come from different cultures and practices in different settings with different cultures (Sukatno \& Lubis, 2019). it shows that as a prospective professional counselor, the counselor must have multicultural competencies that are qualified to prevent various potential counseling services that ignore the cultural values possessed by the counselee.

In preventing the potential of counseling services that ignore cultural values, Derald Wing Sue and colleagues formulated a Multicultural Counseling Competency (MCC) model that contained a tricomponential model (three-component models) consisting of: a) counselor awareness of assumptions, values, and cultural biases owned b)counselors' understanding of the views of diverse cultural groups c) develop techniques and strategies (skills) that are appropriate in communicating with counselees of different cultures (Sue1982, n.d.).

Interviews conducted with five BKPI students at UIN Raden Intan showed that students often faced difficulties in cross-cultural counseling practices because the implementation was only in the form of conceptual studies. Based on the results of the interview, training is needed to improve multicultural competencies that involve students directly in multicultural counseling practices. The preliminary data obtained from the distribution of multicultural competency scales to 80 students resulted in the following categories: 12\% (16 subjects) included in the low category, 52.5\% (42 subjects) in the medium category, and $27.5 \%$ in the high category. (22 subjects).

Efforts have been made to improve multicultural competencies through the development of multicultural competency training guidelines, the application of counseling guidance media, and the application of experiential learning group guidance services. Experiential learning provides hands-on experience to students by providing counseling experiences with counselees with different cultures. Students are given knowledge/information about multicultural competencies and knowledge about several cultures in Indonesia (cultural values, myths, and things to avoid). Research conducted by Djamaluddin shows that the experiential learning model is effective in increasing the multicultural competence of students outside Java. (Djamaluddin, Lasan, \& Atmoko, 2018).

In line with Nurhakim's research, and experiential learning model can build understanding and tolerance across religions (Nurhakim, 2018), Furthermore, experiential learning is successful in increasing the ability of a respectful mind for students (Pangestie \& 
Sendayu, 2016). Multiculturalism develops the Triad Training Model, which aims to explore hidden messages in culture-centered counseling. The experiential learning model can increase the active participation of individuals (students) to develop an awareness of feelings, beliefs, opinions, and attitudes that are owned by others, and individual knowledge can help improve interpersonal relationships between groups of different cultures in a positive way(Calvin \& Igu, 2019). The same results also prove the experiential learning model can improve the ability of individuals to move with friends (Earnest, Rosenbusch, Wallace-Williams, \& Keim, 2016). This model shows us to understand the cultural values of others, and it is necessary to recognize individuals of different cultures thoroughly.

Then, this research applies to awareness training. Awareness training provides an understanding of counseling theory to students to gain an understanding of multicultural competencies through discussion. Research on the awareness training model conducted by Akhmadi explains that this model affects the multicultural awareness of counsellors (Akhmadi, 2013). This awareness training model can effectively apply to multicultural training, which will have a significant influence on the counselor's multicultural awareness. The awareness training model has simple and practical steps to increase counselor's multicultural awareness. (Spieler \& Miltenberger, 2017). The stages in the awareness training model consist of assigning and completing assignments, as well as analyzing these assignments and reflecting back to students. This stage is greatly influenced by trainers who can facilitate the varied affective and cognitive reactions of students to the training process (Van Gordon et al., 2017).

The trainer makes active participants in discussions, presentations, and group work. Other research conducted by Julian to explained that awareness training had proven to increase the adaptation of counselor, so that school guidance and counseling teachers can use awareness training techniques not only to improve self-adjustment but to help people be able to provide appropriate services to their counselors (Julianto, Wagimin, \& Muslim, 2016). Furthermore, awareness training is also capable of improving prosocial work leaders (Dimoff, Kelloway, \& Burnstein, 2016). Based on the description, concluded the multicultural competence of BKPI students is the medium category. Efforts are needed to improve these competencies. Therefore this research aims to strengthen the multicultural skills of BKPI students through experiential learning and awareness training.

\section{Methods}

This research is an experimental research, with the experimental design used is trueexperimental design.. The form of research design used is Nonequivalent Control Group Design. The study design based on the selection of non-random subjects. Also, another consideration is because experimental research aims to determine the effect before and after given the intervention and compare the two groups after the given intervention. The following is an overview of research designs. :

\begin{tabular}{lccc}
\hline & Pre-test & Intervention & Post-tets \\
\hline Experiment Group & O1 & X1 & O2 \\
Control group & O1 & X2 & O2 \\
\hline
\end{tabular}

Figure 1. Experimental Research Design

Pretest first $(\mathrm{O} 1)$ before the intervention, then the intervention in the experimental group in the form of training with experiential learning model (X1) and the control group intervention in the form of exercise with awareness training model (X2). After the intervention, each group given a posttest $(\mathrm{O} 2)$.

This study uses three variables, namely two independent variables and the dependent variable. The independent variables in this research are the experiential learning model and 
awareness training model. The dependent variable in this research is multicultural competence. This study aims to examine the effectiveness of experiential learning models to improve the multicultural competency of prospective counselors.

In the study population used was the six-semester student of the BKPI Study Program at UIN Raden Intan Lampung. Based on these populations, the research subjects were taken by Purposive Sampling that met the criteria set by the researcher. The research subjects divided into two groups: the experimental group intervention using the experiential learning model and the control group with the awareness training model.

The instruments used in this study were of three types, namely treatment materials in the form of multicultural competency training steps using experiential learning, multicultural competency training steps with awareness training models, and data collection instruments, namely the multicultural competency scale. The training procedure is designed concerning the experiential learning stages, namely, Concrete Experience, Reflective Observation, Abstract Conceptualization, and Active Experimentation. The training procedures for the awareness training model that were developed included discussion, presentation, and reflection as a form of an exploration process for the counselor's self-experience, training using self-exploration techniques to evaluate core values, beliefs, and outlook on life.

The multicultural competency scale will use to measure the level of multicultural competence of students before and after an intervention is given. Therefore, the scale of multicultural competence will be the main instrument in determining the effectiveness of interventions carried out. The designed multicultural competency scale refers to the construct of Pedicen's multicultural competency theory.

Hypothesis testing in this study uses non-parametric statistical analysis consisting of the Wilcoxon Signed Rank Test and the Mann Whitney U Test. The statistical analysis of the Wilcoxon Signed Rank Test used to compare the average scores before and after the treatment or intervention is given to the experimental and control groups. While the Mann Whitney $U$ test used to compare the average scores of the experimental group and the control group after given intervention. Although this study uses two statistical analyzes, Wilcoxon Signed Rank Test and the Mann Whitney U Test, and hypothesis testing refers to the analysis of the Mann Whitney $U$ test with HO decision provisions, which state that there is no significant difference in scores. Angry emotions in the experimental group. And the control group after being given treatment. In contrast, Ha there are differences in the scores of the experimental group and the control group after an intervention is given.

\section{Results and Discussion}

At the beginning of the study, a pretest with a multicultural competency scale was conducted to measure the level of multicultural competence of students before being given treatment. The pretest results showed that the study population of 80 subjects had a level of multicultural competence in the low category of $12 \%$ (16 subjects), the moderate category $52.5 \%$ (42 subjects), and the high category of $27.5 \%$ (22 subjects). This study focused on samples that fall into the low category and are divided into two groups: the experimental group and the control group.

After being treated using the experiential learning and awareness training model, measurements were taken to re-increase the multicultural competency value of each group. An increase in multicultural competency scores was analyzed using a Wilcoxon signed-rank test analysis; then, hypothesis testing was performed using the Mann-Whitney $U$ test analysis.

The average value of the experimental group before and given treatment with experiential learning models showed a higher increase than the control group. Before being given a treatment of 35.75 , after being given the procedure, it increased to 68.5. In the control group, the average value obtained before treatment was 34.75 , and after being treated with 
the awareness training model rose to 64.40 . The more significant increase in the multicultural competency of the experimental group by 30.75 indicates that the experiential learning model is more effective. Furthermore, hypothesis testing uses the Mann-Whitney U Test analysis to find out the most effective model for increasing multicultural competence. Analyst results show that the value of the $\mathrm{Z}$ Test is -3,386 and the Asym.sig. (2-tailed) score is 0.001 . It is referring to the Asymp. Sig value (2 tailed) of 0.001 smaller than 0.05, it is known that there are significant differences between groups given the experiential learning model and awareness training.

The results show that the average score of the experimental group and the control group both increase. However, the score of the experimental group was higher than the rank of the control group. The increase is due to the effect of providing treatment using an experiential learning model and awareness training. Research shows the experiential learning model is more effective than the awareness training model. This effectiveness is by previous study conducted by researchers to obtain effective experiential learning models to improve multicultural competence (Djamaluddin et al., 2018; Fawcett \& Evans, 2012). By providing direct experience, a person will construct his learning experience as a result of learning.

The experiential learning model has advantages in the learning process that provides direct experience as a result of learning. In this study, students were given counseling practices with counselees from different cultural backgrounds. The experiential learning model conducted in this study refers to four stages: concrete experience, reflective observation, abstract conceptualization, and active experience (Kolb \& Kolb, 2009). The advantages of this study are students get direct experience because they get information about the views of each counseling approach about culture. They practice it and reflect on each of the giving of learning experiences that are useful for further learning. Experiential learning can stimulate individual multicultural awareness. In the experiential learning model research not only emphasizes aspects of multicultural development but also increases the knowledge and skills that are very important possessed by prospective counselors (Tomkins \& Ulus, 2016).

This research has supported the results of the study which states that prospective counselors should obtain changes as a result of learning, at least there is a change in the level of reflectivity, changes in autonomy and communication skills and can be raised with experiential learning models (Andrianie, Muslihati, \& Ramli, 2019). Two important aspects that must be considered in experiential learning so that it runs well is the use of concrete experiences and occur directly (here and now) (Jose, Patrick, \& Moseley, 2017). The experiential learning process will useful when individuals can present directly experienced experiences, so individuals can describe in detail the skills gained by involving affective and cognitive aspects. Also, experiences that can occur within a short span of the experiential learning process, so that individuals will be younger considering in detail the skills experienced, conversely if the expertise used in the experiential learning process is longstanding, then individuals have limitations to reflect on. Meanwhile, awareness training places more emphasis on students' discussion processes regarding the views of counseling approaches on cultural issues and analyzing multicultural counseling process videos. Awareness Training is a choice because it has a practical and straightforward syntax, an essential component of the awareness training model that can sharpen awareness is individuals who are related to cultural differences.

The awareness training model also succeeded in increasing students' multicultural competence by providing a discussion on a topic about the views of each counseling approach on culture, even discussing the issue of cultural diversity in the classroom and society. Other research also proves that this model can increase multicultural competence and multicultural awareness of individuals (Situmorang, Bisri, \& Setiono, 2018). The success of 
the awareness training model has been proven to students to increase learning motivation, the results of the subject's research have improved learning motivation, especially physics, the awareness training research emphasizes interpersonal and personal development, and students are required to explore themselves to be responsible in solving problems that will be given by a teacher and can foster students' curiosity which then will also realize personally how necessary self-control (emotional students) in do cooperation as a solution to complete the tasks that have given (Taufiq, Tina, \& Djafar, 2019).

Furthermore, the use of awareness training models is proven effective when combined with the constructivism model; the use of one awareness training model is not practical in increasing the acquisition of science concepts (Sandhu \& Sidhu, 2015). The awareness training model will be more effective if it is complete with a learning strategy in the form of showing films and videos (audiovisual), lectures with the help of powerpoint media, games, discussions, and group work (Akhmadi, 2013). In this study, there were no games, explanations of the material with powerpoints, and films related to multicultural competencies; students were only asked to discuss and analyze video counseling sessions. The exciting thing in this research is the combination of experiential learning model, and awareness training model can increase self-understanding and awareness of other people's behavior, as well as more creative knowledge so that it can help in developing personal and social development.

\section{Conclusions and Suggestions}

Based on the results of the study, it can be concluded that the two models used are experiential learning and awareness training, effectively increasing the multicultural competence of BKPI students at UIN Raden Intan Lampung. Students experience an increase in multicultural awareness, knowledge, and skills. In this study, the experiential learning model is more effective because it provides direct experience for students to practice counseling..

Based on the research results obtained, the advice given to guidance and counseling study programs to design training programs that facilitate prospective counselors to improve multicultural competence. Also, the application of the experiential learning model needs to deepen awareness and knowledge possessed by prospective counselors about the culture of the society in Indonesia by implementing counseling practices with counselees who have diverse cultural backgrounds so that the experience gained is more contextual and factual. Researchers can then develop awareness training models to improve one aspect of other multicultural competencies and use films or games to help students gain more experience.

\section{References}

Akhmadi, A. (2013). Peningkatan Kesadaran Multikultural Konselor (Guru BK). Muaddib, $3(2), 18-36$.

Andrianie, S., Muslihati, M., \& Ramli, M. (2019). Pengembangan Paket Bimbingan Berbasis Experiential learning untuk Meningkatkan Empati Siswa Sekolah Dasar. Ilmu Pendidikan: Jurnal Kajian Teori Dan Praktik Kependidikan, 3(2), 196-202.

Bulantika, S. Z. (2017). Pengaruh Persepsi Masyarakat Terhadap Kecemasan Kaum Homoseksual/Lesbian. JURNAL EDUKASI: Jurnal Bimbingan Konseling, 3(2), 158173.

Calvin, J. R., \& Igu, J. (2019). Culture, Conflict and Team Management in I4H: Experiential Learning in Business Practice to Support Community Development Entrepreneurship. Journal of Organizational Culture, Communications and Conflict. 
Charlina, R., Utama, T. C., \& Farabi, N. (2017). 5. Combating Cyber Racism: Analisis Komparatif terhadap Implementasi Protokol Tambahan Council of Europe Convention on Cybercrime tentang Cyber Racism (CETS 189) di Amerika Serikat dan Australia Tahun 2012-2016. Journal of International Relations, 3(1), 39-47.

Dimoff, J. K., Kelloway, E. K., \& Burnstein, M. D. (2016). Mental health awareness training (MHAT): The development and evaluation of an intervention for workplace leaders. International Journal of Stress Management, 23(2), 167.

Djamaluddin, M., Lasan, B. B., \& Atmoko, A. (2018). Experiential Learning untuk Meningkatkan Kompetensi Multikultural Mahasiswa. Jurnal Kajian Bimbingan Dan Konseling, 3(3), 119-130. https://doi.org/10.17977/um001v3i32018p119

Earnest, D. R., Rosenbusch, K., Wallace-Williams, D., \& Keim, A. C. (2016). Study abroad in psychology: Increasing cultural competencies through experiential learning. Teaching of Psychology, 43(1), 75-79.

Fawcett, M. L., \& Evans, K. M. (2012). Experiential approach for developing multicultural counseling competence. In Experiential Approach for Developing Multicultural Counseling Competence. https://doi.org/10.4135/9781452244075

Jose, S., Patrick, P. G., \& Moseley, C. (2017). Experiential learning theory: the importance of outdoor classrooms in environmental education. International Journal of Science Education, Part B, 7(3), 269-284.

Julianto, B., Wagimin, \& Muslim, M. (2016). Keefektifan Self-Awareness Training untuk Meningkatkan Penyesuaian Diri Peserta Didik. Jurnal Program Studi Bimbingan Dan Konseling, 4(June), 0-5.

Kolb, A. Y., \& Kolb, D. A. (2009). The Learning Way. Simulation \& Gaming, 40(3), 297327. https://doi.org/10.1177/1046878108325713

Nurhakim, M. (2018). Islamic Education Based in Multiculturalism Through Experiential Learning Approach at University of Muhammadiyah Malang. 2018 3rd International Conference on Education, Sports, Arts and Management Engineering (ICESAME 2018). Atlantis Press.

Pangestie, E. P., \& Sendayu, F. S. (2016). Pendekatan Experiential Learning Untuk Meningkatkan Kemampuan respectful mind Bagi Mahasiswa. Jurnal Penelitian Tindakan Bimbingan \& Konseling, 2(1).

Ridwan. (2015). Problematika Keragaman Kebudayaan Dan Alternatif Pemecahan. Jurnal Madaniyah, 2, 254-270.

Riswanto, D., Mappiare-AT, A., \& Irtadji, M. (2017). Kompetensi Multikultural Konselor pada Kebudayaan Suku Dayak Kalimantan Tengah. JOMSIGN: Journal of Multicultural $\begin{array}{llll}\text { Studies in } \quad \text { Guidance } & 15 .\end{array}$ https://doi.org/10.17509/jomsign.v1i2.8320

Sandhu, B. K., \& Sidhu, R. K. (2015). Awareness Training Model and Constructivism as Related to Acquisition of Concepts of Science.

Situmorang, D. D. B., Bisri, M., \& Setiono, L. (2018). Model awareness training untuk meningkatkan kesadaran multikultural konselor.

Spieler, C., \& Miltenberger, R. (2017). Using awareness training to decrease nervous habits during public speaking. Journal of Applied Behavior Analysis, 50(1), 38-47.

Sue1982. (n.d.). 
Sukatno, S., \& Lubis, R. F. (2019). Konseling Antar Budaya Terhadap Perkawinan Batak Toba dan Nias di Kecamatan Sibabangun. RISTEKDIK: Jurnal Bimbingan Dan Konseling, 4(2), 127-133.

Tangidy, A. M., \& Setiawan, T. A. (2016). Toleransi melalui model budaya Pela Gandong menggunakan media board game untuk mahasiswa. Sabda: Jurnal Kajian Kebudayaan, 11(2), 16-25.

Taufiq, A. U., Tina, K. T., \& Djafar, H. (2019). Pengaruh Model Pembelajaran Awareness Training Terhadap Motivasi Belajar Fisika. Jurnal Pendidikan Fisika, 7(1), 10-16.

Tomkins, L., \& Ulus, E. (2016). 'Oh, was that “experiential learning”?!'Spaces, synergies and surprises with Kolb's learning cycle. Management Learning, 47(2), 158-178.

Van Gordon, W., Shonin, E., Dunn, T. J., Garcia-Campayo, J., Demarzo, M. M. P., \& Griffiths, M. D. (2017). Meditation awareness training for the treatment of workaholism: A controlled trial. Journal of Behavioral Addictions, 6(2), 212-220.

Yusra, T. (2018). Konseling realitas : meningkatkan sikap toleran siswa terhadap keragaman budaya. 2(1), 32-37. 